\title{
Antioxidant Activities of Some Spices and Herbs Added to Frozen Chicken Burger
}

\author{
Soumia M.I. Darwish ${ }^{1}$, Mohame d. A. H. El-Geddawy ${ }^{1}$, Reda M. B. Khalifa ${ }^{2}$, Rewaa A. A. Mohamed ${ }^{2, *}$ \\ ${ }^{1}$ Food Science and Technology Dept. Faculty of Agric. Assiut Univ. Assiut, 71526, Egypt \\ ${ }^{2}$ Food Technology Research Institute, Agricultural Research Center, Giza, 12619, Egy pt
}

\begin{abstract}
The main objective of the present study was carried to evaluate the possibility of using spices and herbs (thyme, rosemary, sage, marjora m and black seeds) as natural antio xidants to help chic ken burger industry to min imize lipid oxidation and extend the shelf-life of chicken burger. Two concentrations of these plants $(0.5$ and $1 \%)$ were added to chicken burger and stored at $-18^{\circ} \mathrm{C}$ for 6 months. Fat content, thiobarbituric acid values (T.B.A) and peroxide value (P.V) were determined. Study indicated that, there were slight increases in crude fat contents of all samples during freezing storage. Furthermo re, during storage the thiobarbituric acid values (T.B.A) and peroxide value (P.V) for all samples increased as storage period increased. Meanwhile, treatments which had spices and herbs at levels $1 \%$ showed slight decrease in (T.B.A) values and (P.V) compared with control and treat ments which had spices and herbs at leve1 $0.5 \%$. A lso, the results appeared that thyme was the most efficient protection against lipid oxidation followed by sage, rosemary and then marjoram while black seeds gave less effect. Essential oils of thyme, rosemary, sage, marjoram and black seeds were obtained by steam distillation and the chemical composition of each oils were determined by gas liquid chro matographic technique. The fractionated and identified chemical structures of spices and herbs volatile oils showed that, there were 11 components isolated from thy me volatile oil, just 9 components of them were identified. 19 co mpounds were isolated from rosemary volatile oil, but just 12 components were identified. Chemical composition of sage volatile oil, about 19 compounds were isolated from the oil, only 12 compounds were identified from them. 16 components isolated from marjoram volatile oil, only 14 of them were identified. Finally, 17 components is olated from black seeds volatile oil, only 10 co mponents of them were identified.
\end{abstract}

Keywo rds Antioxidant, Thyme, Sage, Rosemary, Marjoram, Black Seeds

\section{Introduction}

Changes in eating habits arising from the development of society in recent decades have led people to search for affordable and healthier foods with satisfactory taste and pleasant appearance. Thus, the food industry continually seeks to adapt and develop new formulations designed to increase shelf life and to improve quality and food safety. Chicken meat, especially its industrial products, presents serious problems of processing and storage. Unsaturated lipids, fine grinding, incorporation of air, haem pigments, metal contact and high temperature during processing contribute to lip id o xidation[1]. A fter mic robial deterioration, lipid oxidation is the main process that results in loss of quality[2]. Lipid oxidation generates undesirable products from the sensory point of view, making the food unfit for consumption. In addition, it causes the degradation of fat soluble vitamins and essential fatty acids, and it interferes with the integrity and safety of foods through the formation

* Corresponding author:

rewaaahmed@ymail.com (Rewaa A. A. Mohamed)

Published online at http://journal.sapub.org/f

Copyright (C) 2012 Scientific \& Academic Publishing. All Rights Reserved of potentially toxic compounds[3], such as malonaldehyde (MDA). In an attempt to control this process, food industries use synthetic additives with antioxidant properties. However, due to reports of possible toxic effects from synthetic antioxidants and to increas ingly demanding consumer preferences for natural products and health benefits, the interest foralternative methods to retard lipid oxidation in foods, such as the use of natural antio xidants, has increased. These methods include spice extracts[4], fruit juice[5], tea extracts[6], seed extracts[7] and others. Plants, including herbs and spices, have many phytochemicals which are potential sources of natural antioxidants, e.g. phenolic diterpenes, flavonoids, tannins and phenolic acids[8]. These compounds have antioxidant, anti-inflammatory and anticancer activities [9].

The objective of the present study was carried out to investigate the feasibility of using selected natural spices and herbs for improving the lipid stability extending the shelf life of chicken burger during freezing storage and identification of chemical composition of chosen spices and herbs volatile oils.

\section{Materias and Methods}




\subsection{Materials}

\subsubsection{Chicken Meat}

$10 \mathrm{~kg}$ of fresh chicken meat from broiler carcasses (7-8 weeks age with an average weight $1.5-2 \mathrm{~kg}$ ) were obtained from El-Borssa Company for Poultry at February 2010. On receipt at the laboratory, they were washed carefully then deboned within two hours of slaughtering, the chicken meat was minced using a meat mincer and then chilled at $4 \pm 1^{\circ} \mathrm{C}$ for 24hours before using in processing of chicken burgers.

\subsubsection{Selection of Spices and Herbs}

Selected spices and herbs were used in chicken burger formula namely thyme (thymus vulgaris L.), rosemary (Rosmarinus officinalis L.), black seeds (Nigella sativa L.), sage (Salvia officinalis), and marjoram (Origanum majoranum), were obtain from the Agricultural Research Center, Giza, Egypt.

\subsubsection{Salt, On ion, Whole Egg and Bread Crust Powder}

Salt, onion, whole egg and bread crust powder were obtained from the local market and used for preparation of chicken burger. While, soy flour was purchased from the Food Technology Research Institute. Agricultural Research Center-Giza, Egypt.

\subsection{Methods}

\subsubsection{Preparation of Chicken Burger}

Fresh chicken burger samp les were prepared as described by[10]. All ingredients were minced twice, after mincing, the chicken mixture was shaped manually using a patty marker (stainless steel model "Form") to obtain round discs $10 \mathrm{~cm}$ diameter and $0.5 \mathrm{~cm}$ thickness. Burgers were packaged in polyethylene bags (in foam dishes).

- The Basal constituents of chicken burger were prepared as follows:

The chilled minced chicken meat formula included fat $71.5 \%$, fresh onion (finely ground) $7.0 \%$, whole egg (blended) $5.0 \%$, bread crust powder $5.0 \%$, rehydrated extruded soy $10.0 \%$ and sodium chloride $1.50 \%$. These ingredients were mixed together, divided to eleven equal portions, the first portion was remained without any addition (control) and the ten reminder portions were individually mixed with two concentrations of each spices and herbs $\quad(0.5 \%$ and $1 \%)$ to give ten treatments . All burgers treatments and control were freeze stored at $-18 \pm 2^{\circ} \mathrm{C}$ up to 6 months.

\subsubsection{Analytical Methods}

Fresh chicken meat used in this study was analyzed immediately upon receipt at the laboratory for chemical analyses, as well as immediately after manufacturing (zerotime analyses), and then after 1, 2, 3, 4, 5 and 6 months of frozen storage at $-18 \pm 2^{\circ} \mathrm{C}$.

\subsubsection{Crude Fat Contents}

Crude fat determined according to the methods described by[11].

\subsubsection{Thiobarbituric Acid Value (T.B.A)}

Thiobarbituric acid (TBA) values were determined in chicken burger samples at $0,1,2,3,4,5$ and 6 months of storage at $-18^{\circ} \mathrm{C}$ accord ing to the method of [12] to evaluate efficiency of additives as natural antioxidants. Twenty $\mathrm{g}$ sample plus $40 \mathrm{ml}$ of trichloroacetic acid $(7.5 \%)$ were homogenized for 1 minute and left for 30 minutes. Filtration was carried out using whatman No. 1 filter paper. Five ml of the filtrate mixed with $5 \mathrm{ml}$ of TBA solution $(0.2883 \mathrm{~g}$ TBA/ $100 \mathrm{ml}$ water) in a test tube. Blank was carried out using $5 \mathrm{ml}$ distilled water and $5 \mathrm{ml}$ TBA solution. Tubes were covered and heated in boiling water bath for $40 \mathrm{~min}$, then after rapid cooling in ice bath, absorbance at $538 \mathrm{~nm}$ was measured using ultraviolet visible scanner Spectrophotometer (LKB 4054 Cambridge, England). The TBA values were calculated by mult iply ing the absorbance by the factor of 7.8 and the result was represented as $\mathrm{mg}$ of malonaldehyde per $1000 \mathrm{~g}$ sample.

\subsubsection{Pero xide Value (P.V)}

Weight $5.00 \pm 0.05 \mathrm{~g}$ sample into $250 \mathrm{~mL}$ g lass-stoppered Erlen meyer. Add $30 \mathrm{~mL} \mathrm{CH} \mathrm{COOH}_{3} \mathrm{CHCl}_{3}$ and swirl to dissolve. Add $0.5 \mathrm{~mL}$ saturated $\mathrm{Kl}$ solution fro $\mathrm{m} \mathrm{Mohr} \mathrm{pipet,}$ let stand with occasional shaking $1 \mathrm{~min}$, and add $30 \mathrm{~mL} \mathrm{H}_{2} \mathrm{O}$. Slowly titrate with $0.1 N \mathrm{NA}_{2} \mathrm{~S}_{2} \mathrm{O}_{3}$ with vigorous shaking until yellow is almost gone. Add ca $0.5 \mathrm{~mL} 1 \%$ starch solution, and continue titration, shaking vigorously to release all $\mathrm{I}_{2}$ fro $\mathrm{CHCl}_{3}$ layer, until blue just disappears. If $<0.5 \mathrm{~mL} 0.1 N \mathrm{Na}_{2} \mathrm{So}_{3}$ is used

Conduct blank determination daily (must be $<0.1 \mathrm{mLO}$ $0.1 \mathrm{~N} \mathrm{Na}_{2} \mathrm{So}_{3}$ ). Subtract fro m sample titration.

Pero xide value (milliequivalent pero xide/ $\mathrm{Kg}$ sample) $=\mathrm{S}$ x $\mathrm{N} \times 1000 / \mathrm{g}$ sample, where $\mathrm{S}=\mathrm{mL} \mathrm{Na}_{2} \mathrm{So}_{3}$ (blank corrected) and $N$ normality $\mathrm{Na}_{2} \mathrm{~S}_{2} \mathrm{O}_{3}$ solution[11].

\subsubsection{Extraction of Essential Oils}

The volatile oils of chosen spices and herbs (used in burger formula) were extracted from their spice and herbs, using steam distillation method in a glass apparatus for 4-6 hours. The extracted volatile oils were dried over anhydrous sodium sulphate before held in dark glass bottles at $-20^{\circ} \mathrm{C}$ according to the method of [11].

\subsubsection{Classification and Identification of Essential Oil Components in Spices and Herbs}

- Gas chromatographic analyses:

The volatile oil was analyzed using DsChrom 6200 Gas Chromatographic equipped with a flame ionization detector for separation of volatile oil constituents in Medicinal and Aromatic Plants, Horticulture Research Institute, Agricultural Research Center according to method described by[13]. The analyses conditions were as follows:

1-The chromatographic apparatus was fitted with capillar 
y column BPX-5, 5\% phenyl (equiv.) polysillphenylenesilo xane $30 \mathrm{~m} \times 0.25 \mathrm{~mm}$ ID $\times 0.25 \mu \mathrm{m}$ film.

2-Temperature program ramp increase with a rate of $10^{\circ} \mathrm{C} / \mathrm{min}$ from $70^{\circ}$ to $200^{\circ} \mathrm{C}$.

3-Flow rates of gases were nitrogen at $1 \mathrm{ml} / \mathrm{min}$, hydrogen at $30 \mathrm{ml} / \mathrm{min}$ and $330 \mathrm{ml} / \mathrm{min}$ for air. Detector and injector temperatures were $300^{\circ} \mathrm{C}$ and $250^{\circ} \mathrm{C}$, respectively. The obtained chromatogram and report of GC analyses for each sample were analyzed to calculate the percentage of main components of volatile oil.

\subsubsection{Statistical Analyses}

The data obtained from three replicats were analyzed by ANOVA using the SPSS statistical package program, and differences among the means were compared using the Duncan's Multiple Range test[14]. At a significance level of 0.05 was chosen.

\section{Results and Discussion}

\subsection{Crude Fat Contents}

Data in Table (1) showed that, crude fat contents for all chicken burger samples during freezing storage at $-18^{\circ} \mathrm{C}$ up to 6 months. The results cleared that, during frozen storage there were slight increase with a significant difference in crude fat contents of all different chicken burger treatments under investigation. These increments in crude fat contents of chicken burger during fro zen storage might be due to the decrease of the moisture and crude protein contents during storage. These results are in line with the findings of $[13,15$, 16]. Furthermore, data in the same table revealed that there were a significant difference between control samples and other treatments. Also, there were significant differences in comparison within treatments $(0.5$ and $1.0 \%)$ in most cases.

\subsection{Thiobar bi turic Acid(T.B.A) Values}

Thiobarbituric acid (T.B.A) test is used as an index for measuring oxidative rancidity (malonaldehyde formation) which takes place in chicken meat. The T.B.A test is a sensitive test for the decomposition products of highly unsaturated fatty acids which do not appear in peroxide value determination[17].

Results in Table (2) indicated that the changes of thiobarbituric acid T.B.A values during frozen storage at $-18^{\circ} \mathrm{C}$ up to 6 months for spiced (with powdered spices and herbs) or unspiced chicken burger (as a control), determined as a mg malonaldehyde / $\mathrm{kg}$ sample.

Data showed that, during fro zen storage, the T.B.A value of the control sample showed continuous progressive increases to reach the highest value $(0.700 \mathrm{mg}$ malonaldehyde $/ \mathrm{kg}$ ) at the end of frozen storage periods. Although the other burger treatments showed increment in T.B.A values during frozen storage, these increments were largely lower than that of control sample with a significant difference in some cases. In regard to these results, burger samples formulated with spices and herbs at level $1 \%$ had the lowest T.B.A values at the end of frozen storage, while those samples formulated with spices and herbs at level $0.5 \%$ had higher T.B.A values with no significant difference compared within each treatment. The slight increases in T.B.A values of different chicken burger treatments compared with control, could be attributed to the antioxidant activity of some spices and herbs components especially their volatile oils. This concept is on line with[18]. Generally, during storage the T.B.A values of all samples increased with no significant difference as storage periods increased. These results were in line with $[19,20]$.

However, the sample formulated with thyme at level $1 \%$ had lower T.B.A values compared with sample containing thyme at level $0.5 \%$ and other treatments. At the same time T.B.A values in samples formulated with sage at levels 0.5 and $1 \%$ were lower than these samples formulated with rosemary at levels 0.5 and $1 \%$, respectively. These results are in line with the findings of[21]. Meanwhile, the T.B.A values in samples formulated with rosemary at levels 0.5 and $1 \%$ were lower than samples formulated with marjoram at levels 0.5 and $1 \%$. These results were in agreement with[22]. Furthermore, the T.B.A values recorded in samples formulated with marjoram at levels 0.5 and $1 \%$ were lower than these samples formulated with black seeds at levels 0.5 and $1 \%$.

In general, it could be concluded that addition of spices and herbs at level $1 \%$ caused decrement in T.B.A values in fresh and frozen chicken burger compared with chicken burger formulated with the same spices and herbs at level $0.5 \%$ and unspiced one (control). Also, it could be noticed that thyme showed the highest antioxidant effect for reduction T.B.A values in samples, the effectiveness of decrement followed the sequence:

Thyme $>$ sage $>$ rosemary $>$ marjora $m>$ black seeds

Similar results were obtained by[23] and[24]. On the other hand, the control sample was acceptable for human consumption after 6 months of storage as their T.B.A value reached ( $0.700 \mathrm{mg}$ malonaldehyde / $\mathrm{kg}$ sample). The[25] rejected frozen chicken sausage samples which had more than $0.9 \mathrm{mg}$ malonaldehyde / $\mathrm{kg}$ sample. 

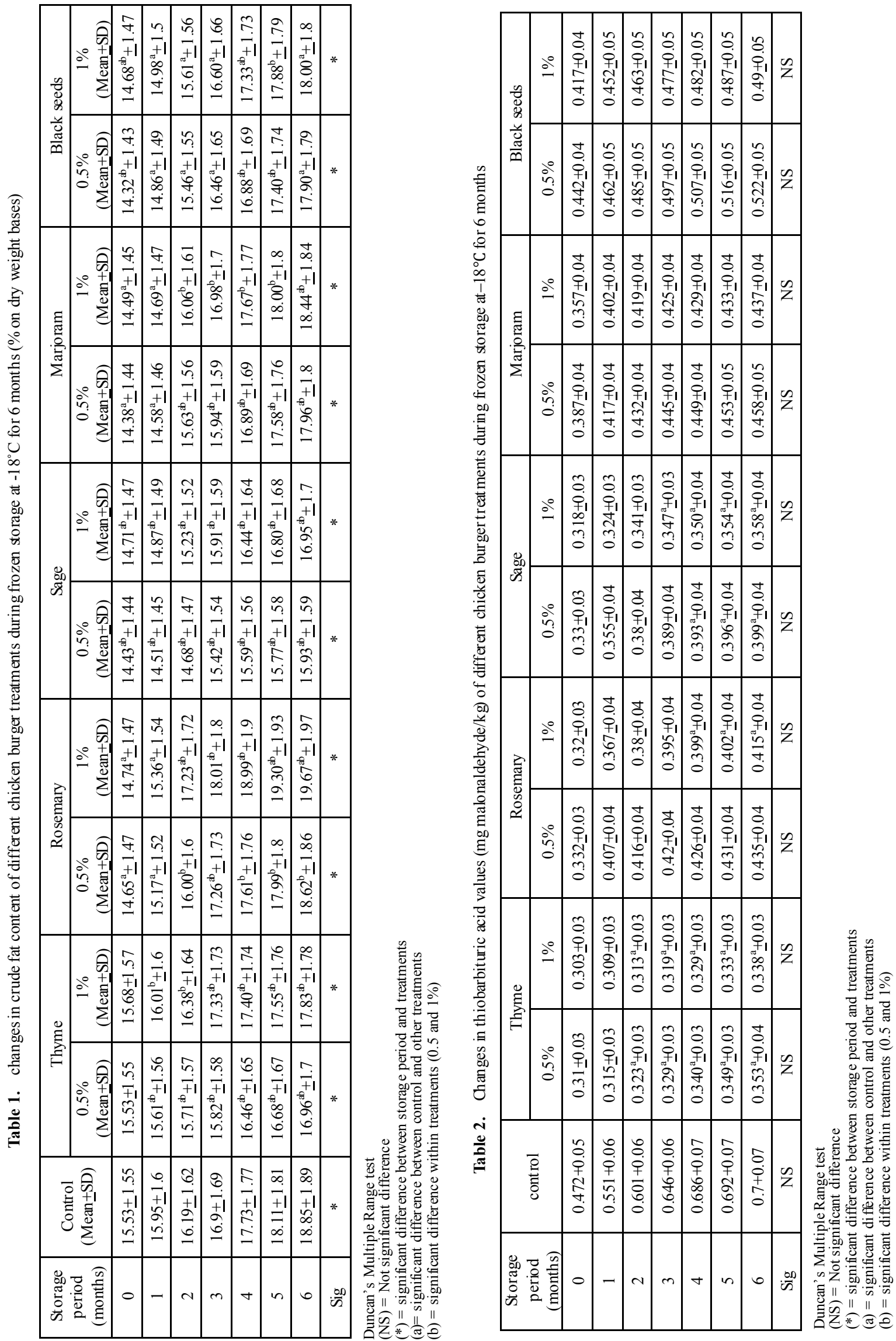


\subsection{Peroxide Values (P.V)}

The peroxide values are used as an index of the degree of oxidative rancidity of lipids. According to[26], fresh edible animal fats which might be stored for long periods, show peroxide values of $2.34 \mathrm{~m}$. equiv./kg fat or less. In comparis on with vegetable oils, this value was lower than the maximum permissible amount given for sun flower seed oil (not more than 10. m. equiv. / $\mathrm{kg}$ fat).

Table (3) cleared that the changes peroxide values of spiced chicken burgers and control sample during frozen storage at $-18^{\circ} \mathrm{C}$ up to 6 months. The recorded data revealed that peroxide values (P.V) had the same trend of T.B.A values. Also, peroxide values in all chicken burger treatments tended to significant increase with the progressive of frozen storage period. These findings are in the line with those obtained by[27,28] and[13].

During freezing storage the chicken burger samples formulated with spices and herbs at level 1\% had lower P.V values than those samples formulated with spices and herbs at level $0.5 \%$ with a significant difference in all cases when compared with in treatments. Furthermore, the control sample had higher P.V value compared with other treatments, this could be attributed to the antioxidant activity of some spices and herbs components. Also, during frozen storage the sample formulated with thyme at level $1 \%$ caused more reduction than the $\mathrm{P}$. V compared to sample formulated with thyme at level $0.5 \%$ and other treatments.

At the same time P.V values recorded in samples formulated with sage at levels 0.5 and $1 \%$ were lower than those samples formulated with rosemary at levels 0.5 and $1 \%$, respectively. Meanwhile, the P.V values in samples formulated with rosemary at levels 0.5 and $1 \%$ were lower than those samples formulated with marjoram at levels 0.5 and $1 \%$. Furthermore, the P.V values in samples formulated with marjoram at levels 0.5 and $1 \%$ were lower than these samples formulated with black seeds at levels 0.5 and $1 \%$.

However, it could be summarized that the addition of spices and herbs at level $1 \%$ caused decrement in $\mathrm{P} . \mathrm{V}$ values in fresh chicken burger compared with chicken burger formulated with spices and herbs at level $0.5 \%$ and unspiced one (control). The present of thyme in chicken burger showed the highest for reducing P.V value in samples. The effectiveness of decrement followed the sequence: Thyme $>$ sage $>$ rosemary $>$ marjoram $>$ black seeds. Similar results were obtained by[23].

\subsection{Classification and Identification of $\mathrm{S}$ pices and Herbs Volatile Oils}

The essential oil was extracted from the investigated spices and herbs by the steam distillation method. In an attempt to define the identity and roles played by chemical components of spices and herbs volatile oils as antioxidant and antimicrobial agents, gas chromatography (GC) was used to fractionate and identify these compounds. The fractionated and identified chemical structures of spices and herbs volatile oils were tabulated in Table (4).
From the data tabulated in Table (4) it could be observed that, there were 11 components is olated from thyme volatile oil, just 9 components of them were identified. The identified compounds represented $98.99 \%$ of the chemical components of thyme volatile oil and could be classified to three chemical categories. The identified chemical groups namely; monoterpene hydrocarbon $(21.74 \%)$, monoterpene phenols $(75.17 \%)$ and sesquiterpenes $(2.10 \%)$. On the other hand, the remaining portion of this volatile oil was $(1.01 \%)$ represented 2 unknown compounds, might be considered as trace compounds in such oil.

Results in Table (4) showed that the first chemical group identified in thyme oil was monoterpene hydrocarbons which contained 7 components namely: $\alpha$-p inene $(0.51 \%)$, sabinene $(1.42 \%), \beta$-pinene $(3.56 \%)$, myrcene $(4.30 \%)$, limonene $(3.34 \%), \rho$-cymene $(1.98 \%)$ and $\gamma$-terpinene $(6.63 \%)$. The second group was monoterpene phenols which included thymol (75.15\%) which was the major component. The third chemical group was sesquiterpenes which contain $\beta$-cayophllene $(2.10 \%)$. [29] determined the major components of thyme essential oil by GC and GC-Mass and they were (carvacrol, thymol, p-cymene and 1,8 cineole).[30] identified the aroma compounds in the extracts of thyme leaves by (GC) and (GC/MS). The major aroma constituents of thyme were thymol $(8.55 \mathrm{mg} / \mathrm{g})$, carvacrol $(0.681 \mathrm{mg} / \mathrm{g})$, linalool $(0.471 \mathrm{mg} / \mathrm{g}), \alpha$-terpineol $(0.291 \mathrm{mg} / \mathrm{g})$ and 1,8 cineole $(0.245 \mathrm{mg} / \mathrm{g})$.

From the Table (4) it could be noticed that, 19 compounds were isolated from rosemary volatile oil, but just 12 components were identified. Those obtained compounds represented $(90.65 \%)$ of chemical components of rosemary volatile oil, these compounds could be classified to four chemical categories, namely; monterpene hydrocarbons $(28.02 \%)$, oxygenated monoterpenes $(51.75 \%)$, monoterpene esters $(9.22 \%)$ and monoterpene phenols $(1.67 \%)$. The remaining portion of volatile oil $(9.35 \%)$, represented 7 unknown compounds might be considered as trace compounds in such oil.

Results in the same table showed that the first chemical group identified in the volatile oil of rosemary was monoterpene hydrocarbons $(28.02 \%)$ which consist of 6 components namely; $\alpha$-pinene (13.60\%), camphene $(4.44 \%)$, $\beta$-pinene (1.99\%), myrcene (1.85\%), limonene $(4.22 \%)$ and $\rho$-cymene $(1.92 \%)$. The second identified chemical group was oxygenated monterpenes $(51.75 \%)$ which consisted of four components were found namely; 1,8-cineole $(15.92 \%)$, linalool (5.85\%), borneol (17.39\%) and citronellol (12.58\%). The third identified group was monoterpene esters which contained only one compound was bornyl acetate $(9.22 \%)$. The fourth chemical group identified in rosemary volatile oil was monoterpene phenols which contained only one compound namely; estragole $(1.67 \%)$. In this concern[31] found that the analys is of the ess ential oil of rosemary by gas chromatography- mass spectrometry showed that eucalyptol, vorneol, $\alpha$-pinene, $\alpha$ - terpineol, camphor and camphene constituted $45.80 \%, 16.51 \%, 6.04 \%, 5.55 \%, 3.00 \%$ and $2.22 \%$ of this essential oil. While,[32] found that, the 
essential oil for rosemary contained $\alpha$-pinene $23.06 \%$, camphene $4.50 \%, \beta$-pinene $2.16 \%$, limonene $3.33 \%$, 1,8 -cineole $8.91 \%, \gamma$-terpinene $1.92 \%$, terpinolene $1.36 \%$, linalool $1.95 \%$, camphor $3.12 \%$, borneol $3.49 \%$, terpinen-4-ol $1.52 \%$, $\alpha$-terpineol $1.70 \%$, myrtenol $1.32 \%$, verbenone $24.11 \%$, geran iol $1.79 \%$, bornyl acetate $5.50 \%$. All these compounds represented $89.74 \%$ of essential oil compounds.

The same table showed the chemical composition of sage volatile oil, about 19 compounds were isolated from the oil, only 12 compounds were identified from them. The identified compounds represented $(91.27 \%)$ from the whole oil constituents and were classified for 6 chemical groups, namely; monoterpene hydrocarbons $(8.58 \%)$, oxygenated monoterpenes $(48.90 \%)$, monoterpene ketones $(25.17 \%)$, monoterpene esters $(5.16 \%)$, monoterpene phenols $(1.10 \%)$ and sesquiterpenes $(2.36 \%)$. The first identified chemical group in Table (4), sage volatile oil was monoterpene hydrocarbons, which consisted of five compound namely; $\alpha$-pinene $(2.17 \%)$, camphene $(1.78 \%), \beta$-pinene $(2.53 \%)$, myrcene $(1.40 \%)$ and $\gamma$-terpinene $(0.70 \%)$. The second chemical groups was oxygenated monoterpenes which contained 1,8 cineole $(43.70 \%)$ and borneol $(5.20 \%)$. The third group $(25.17 \%)$ was monoterpene ketones which contained thujone $(16.27 \%)$ and camphor $(8.90 \%)$. The fourth chemical group was monoterpene esters, which contained bornyl acetate $(5.16 \%)$. The fifth chemical group of sage volatile oil was monterpene phenols, which contained only one compound eugenol $(1.10 \%)$. The sixth chemical group fractionated and identified in sage volatile oil was sesquiterpenes which contained one compound namely; $\beta$ - caryophllen $(2.36 \%)$. Furthermore, the remaining portion of this volatile oil $(8.73 \%)$ represented 7 unknown compounds might be considered as trace compounds.

The chemical composition of sage essential oil has been investigated in various countries.[33] found that the essential oil from sage originating from Jordan contains $\alpha$-pinene, camphene, limonene, 1,8-cineole, $\alpha$ and $\beta$-thujone, camphor, lonalool, linalyl acetate, bornyl acetate and humulene. In the essential oil 29 components were detected, 28 of them were identified and a dominant share had $\alpha$-thujone (29.9\%), $\beta$-thujone (13.68\%), camphor (15.74\%) and 1,8-cineole (12.31\%).[34] found that GC-MS analyses of sage essential oils identified 37 constituents, representing $90.0 \%$ of the total oil. The main components were camphor (24.95\%), 1,8 -cineole (24.75\%) and camphene (7.63\%).

From the results illustrated in Table (4), it could be indicated that there were 16 components isolated from marjoram volatile oil, only 14 of them were identified. These components could be classified into five chemical categories namely; monoterpene hydrocarbons (47.34\%), oxygenated monterpenes $(43.08 \%)$, monoterpenes esters $(1.04 \%)$, monoterpenes phenols $(4.32 \%)$ and esequiterpenes $(1.17 \%)$. These identified compounds accounted for (96.95\%) of the composition of marjoram volatile oil. The remaining portion $(3.05 \%)$ was represented by 2 unknown constituents.

Table 3. Changes in peroxide values ( $\mathrm{m}$. equiv. $\mathrm{kg}$ fat) of different chicken burger treatments during frozen st orage at $-18^{\circ} \mathrm{C}$ for 6 months

\begin{tabular}{|c|c|c|c|c|c|c|c|c|c|c|c|}
\hline \multirow{2}{*}{$\begin{array}{l}\text { Storage } \\
\text { Period( } \\
\text { months) }\end{array}$} & \multirow{2}{*}{ control } & \multicolumn{2}{|c|}{ Thyme } & \multicolumn{2}{|c|}{ Rosemary } & \multicolumn{2}{|c|}{ Sage } & \multicolumn{2}{|c|}{ Marjoram } & \multicolumn{2}{|c|}{ Black seeds } \\
\hline & & $0.5 \%$ & $1 \%$ & $0.5 \%$ & $1 \%$ & $0.5 \%$ & $1 \%$ & $0.5 \%$ & $1 \%$ & $0.5 \%$ & $1 \%$ \\
\hline 0 & $6 \pm 0.6$ & $0.0^{\mathrm{ab}} \pm 0$ & $0.0^{\mathrm{ab}} \pm 0$ & $1.4^{\mathrm{ab}} \pm 0.14$ & $0.8^{\mathrm{ab}} \pm 0.08$ & $1.0^{\mathrm{ab} \pm 0.1}$ & $0.0^{\mathrm{ab}} \pm 0$ & $1.6^{\mathrm{ab}} \pm 0.16$ & $1.0^{\mathrm{ab}} \pm 0.1$ & $4.0^{\mathrm{ab}} \pm 0.4$ & $2.0^{\mathrm{ab}} \pm 0.2$ \\
\hline 1 & $7 \pm 0.7$ & $0.8^{\mathrm{ab}} \pm 0.08$ & $0.4^{\mathrm{ab}} \pm 0.04$ & $2.0^{\mathrm{ab}} \pm 0.2$ & $1.4^{\mathrm{ab}} \pm 0.14$ & $1.8^{\mathrm{ab}} \pm 0.18$ & $1.0^{\mathrm{ab}} \pm 0.1$ & $2.2^{\mathrm{ab}} \pm 0.22$ & $1.6^{\mathrm{ab}} \pm 0.16$ & $4.8^{\mathrm{ab}} \pm 0.48$ & $2.4^{\mathrm{ab}} \pm 0.24$ \\
\hline 2 & $7.6 \pm 0.76$ & $1.4^{\mathrm{ab}} \pm 0.14$ & $0.6^{\mathrm{ab}} \pm 0.06$ & $2.8^{\mathrm{ab}} \pm 0.28$ & $2.0^{\mathrm{ab}} \pm 0.2$ & $2.0^{\mathrm{ab}} \pm 0.2$ & $1.6^{\mathrm{ab}} \pm 0.16$ & $3.2^{\mathrm{ab}} \pm 0.32$ & $2.2^{\mathrm{ab}} \pm 0.22$ & $5.6^{\mathrm{ab}} \pm 0.56$ & $3.4^{\mathrm{ab}} \pm 0.34$ \\
\hline 3 & $8 \pm 0.8$ & $1.8^{\mathrm{ab}} \pm 0.18$ & $1.0^{\mathrm{ab}} \pm 0.1$ & $3.6^{\mathrm{ab}} \pm 0.36$ & $2.6^{\mathrm{ab}} \pm 0.26$ & $2.4^{\mathrm{ab}} \pm 0.24$ & $2.0^{\mathrm{ab}} \pm 0.2$ & $3.8^{\mathrm{ab}} \pm 0.38$ & $2.8^{\mathrm{ab}} \pm 0.28$ & $6.0^{\mathrm{ab}} \pm 0.6$ & $4.0^{\mathrm{ab}} \pm 0.4$ \\
\hline 4 & $8.4 \pm 0.84$ & $2.0^{\mathrm{ab}} \pm 0.2$ & $1.2^{\mathrm{ab}} \pm 0.12$ & $3.8^{\mathrm{ab}} \pm 0.38$ & $2.8^{\mathrm{ab}} \pm 0.28$ & $2.8^{\mathrm{ab}} \pm 0.28$ & $2.2^{\mathrm{ab}} \pm 0.22$ & $4.0^{\mathrm{ab}} \pm 0.4$ & $3.0^{\mathrm{ab}} \pm 0.3$ & $6.4^{\mathrm{ab}} \pm 0.64$ & $4.2^{\mathrm{ab}} \pm 0.42$ \\
\hline 5 & $9 \pm 0.9$ & $2.4^{\mathrm{ab}} \pm 0.24$ & $1.6^{\mathrm{ab}} \pm 0.16$ & $4.0^{\mathrm{ab}} \pm 0.4$ & $3.0^{\mathrm{ab}} \pm 0.3$ & $3.0^{\mathrm{ab}} \pm 0.3$ & $2.4^{\mathrm{ab}} \pm 0.24$ & $4.2^{\mathrm{ab}} \pm 0.42$ & $3.2^{\mathrm{ab}} \pm 0.32$ & $6.8^{\mathrm{ab}} \pm 0.68$ & $4.4^{\mathrm{ab}} \pm 0.44$ \\
\hline 6 & $9.2 \pm 0.92$ & $2.8^{\mathrm{ab}} \pm 0.28$ & $1.8^{\mathrm{ab}} \pm 0.18$ & $4.2^{\mathrm{ab}} \pm 0.42$ & $3.4^{\mathrm{ab}} \pm 0.34$ & $3.2^{\mathrm{ab}} \pm 0.32$ & $3.0^{\mathrm{ab}} \pm 0.3$ & $4.4^{\mathrm{ab}} \pm 0.44$ & $3.6^{\mathrm{ab}} \pm 0.36$ & $7.2^{\mathrm{ab}} \pm 0.72$ & $4.8^{\mathrm{ab}} \pm 0.48$ \\
\hline Sig & * & * & * & * & * & * & * & * & * & * & * \\
\hline
\end{tabular}

Duncan's Multiple Range test

(NS) = Not significant difference

$(*)=$ significant difference between storage period and treatments

(a) = significant difference between control and other treatments

(b) = significant difference within treatments $(0.5$ and $1 \%)$ 
Table 4. Chemical components of spices and herbs volatile oils (\%)

\begin{tabular}{|c|c|c|c|c|c|}
\hline Chemical compounds & Thyme & Rosemary & Sage & Marjoram & Black seeds \\
\hline \multirow{2}{*}{\multicolumn{6}{|c|}{$\begin{array}{c}\text { Hydrocarbons } \\
1-\text { Monoternene hydrocarbons. }\end{array}$}} \\
\hline & & & & & \\
\hline$\alpha$-pinene & 0.51 & 13.60 & 2.17 & 3.08 & 2.88 \\
\hline Camphene & ND & 4.44 & 1.78 & 11.78 & 3.77 \\
\hline$\beta$-Pinene & 3.56 & 1.99 & 2.53 & 4.74 & 6.91 \\
\hline Myrcene & 4.30 & 1.85 & 1.40 & 18.79 & 1.95 \\
\hline$\gamma$-Terpinene & 6.63 & ND & 0.70 & 1.70 & ND \\
\hline Sabinene & 1.42 & ND & ND & 1.10 & 6.62 \\
\hline Limonene & 3.34 & 4.22 & ND & 4.00 & 9.98 \\
\hline$\rho$ - cymene & 1.98 & 1.92 & ND & 2.15 & 41.62 \\
\hline \multicolumn{6}{|c|}{ 2-Oxygenat ed monoterpenes: } \\
\hline 1,8 cineole & ND & 15.92 & 43.70 & ND & ND \\
\hline Linalool & ND & 5.85 & N.D & 2.07 & ND \\
\hline Borneol & ND & 17.39 & 5.20 & 7.57 & ND \\
\hline Citronellol & ND & 12.58 & ND & ND & 4.02 \\
\hline Terpinene -4 -ol & ND & ND & ND & 33.44 & ND \\
\hline \multicolumn{6}{|l|}{ 3-Monoterpene phenols: } \\
\hline Thymol & 75.15 & ND & ND & ND & ND \\
\hline Eugenol & ND & 1.67 & ND & ND & ND \\
\hline Estragole & ND & N.D & 1.10 & 4.32 & ND \\
\hline \multicolumn{6}{|l|}{ 4- Monoterpene esters } \\
\hline Bomyl acetate & ND & 9.22 & 5.16 & N.D & ND \\
\hline Linayl acetate & ND & ND & ND & 1.04 & ND \\
\hline \multicolumn{6}{|l|}{ 5- Monot erpene ketones: } \\
\hline Thymoquinone & ND & ND & ND & ND & 4.50 \\
\hline Thujone & ND & ND & 16.27 & ND & ND \\
\hline Camphor & ND & ND & 8.90 & ND & ND \\
\hline \multicolumn{6}{|l|}{ 6-Sesquiterpenes: } \\
\hline$\beta$ - caryophyllene & 2.10 & ND & 2.36 & 1.17 & 1.68 \\
\hline Total known & 98.99 & 90.65 & 91.27 & 96.95 & 83.93 \\
\hline Total unknown & 1.01 & 9.35 & 8.73 & 3.05 & 16.07 \\
\hline
\end{tabular}

"*ND Not Detected"

The chemical constituents of black seeds volatile oil were fractionated and identified by GC techniques. The obtained results were tabulated in Table (4). The results indicated that there were 17 components isolated from black seeds volatile oil, only 10 components of them were identified. These compounds could be classified into four chemical categories, namely; monoterpene hydrocarbons (73.73\%), oxygenated monoterpenes $(4.02 \%)$, monoterpene ketones $(4.50 \%)$ and sesquiterpenes (1.68\%). Also, results in Table (4) showed that, the first chemical group was monoterpene hydrocarbons $(73.73 \%)$ which consist of seven components namely; $\alpha$-pinene $(2.88 \%)$, sabinene $(6.62 \%)$, camphene $(3.77 \%), \beta$ - pinene $(6.91 \%)$, myrcene $(1.95 \%)$, limonene $(9.98 \%)$ and $\rho$-cymene $(41.62 \%)$. The second identified chemical group was oxygenated monoterpenes which contained only one compound namly; citronellal $(4.02 \%)$.

The third identified group was monoterpene ketones which contained only one compound namely; thymoquinone $(4.50 \%)$. The last group was the fourth and was sesquiterpenes which contained $\beta$ - caryophllene $(1.68 \%)$. The remaining portion was unknown constituents ( 7 co mpounds) which represented (16.07\%).

In this concern[37] found that, the gas liquid chromatography of Nigella sativa volatile oil showed that its main constituents were $\rho$-cymene $(31.5 \%)$, thymoquinone $(30.90 \%), \alpha$-pinene $(13.60 \%), \quad \beta$-pinene $(5.20 \%)$, limonene $(3.60 \%)$, carvacrol $(3 \%)$ and thymohydroquinone $(0.90 \%)$. [38] reported that the essential oil percentages of Nigella sativa seed oil was $0.17 \%$ at zero time and it consisted of 20 components: $\alpha$-pinene, camphene, $\beta$-pinene, phellandrene, myrcene, limonene, cineole, $\gamma$-terpinene, $\rho$-cy mene, terpinene, camphor, linalool, caryophllene, humulene, terpineol, cyclohexene-1-ol, cyclohexan dione-2 methyl, citronellol and thymol, in percents $18.79,0.06,3.85,1.82,0.12,1.07,2.30,7.95$, $42.66,5.79,0.32,0.52,1.82,1.39,0.10,0.09,0.19,0.07$, 1.21 and $2.85 \%$, respectively.[39] reported that thymoquinone was the main active constituent in seeds volatile oil and were extensively reported to exhibited protective effect aga inst many diseases depending on its high antioxidant activity.

\section{Conclusions}

Results of the present study demonstrate the positive effects of spices and herbs, added with two concentrations on both retarding lipid oxidation and improving shelf life of chicken burger during frozen storage $\left(-18^{\circ} \mathrm{C}\right)$ for 180 days. The best results were obtained with the concentration of spices and herbs at level $1 \%$ to improve preservation of chicken burger. The highest antio xidant effect was recoded for thyme, followed by sage, rosemary and then marjoram while black seeds gave less inhibitory effect. In addition to, the gas chromatographic (GC) analysis of thyme, rosemary, 
sage, marjoram and black seeds volatile oils, indicated that the number of identified components in these volatile oil were $9,12,12,14$ and 10 compounds, respectively. These compounds representing 98.99, 90.66, 91.27, 96.95 and $83.93 \%$ of the structure of these five volatile oils, respectively. The major compound of these volatile oils were thymol $(75.15 \%)$ for thyme oil, 1,8 cineole $(15.92 \%)$ and borneol $(17.39 \%)$ for rosemary oil, 1,8 cineole $(43.70 \%)$ and thujone $(16.27 \%)$ for sage oil, terpinene-4-ol $(33.44 \%)$ for marjoram oil and $\rho$-cymene (41.62\%) and thymoquinone $(4.50 \%)$ for black seeds oil. Spices, herbs and their essential oils (EOs) are used by the food industry as natural agents for extending the shelf life of foods. A variety of plant- and spice-based antioxidants and antimicrobials is used for reduce oxidation, eliminating pathogenic bacteria, and increasing the overall quality of food products.

\section{ACKNOWLEDGEMENTS}

The authors thanks Meat and Fish Technology Department Research Institute and Medicinal and Aromatic Plants, Horticulture Research Institute, Agriculture Research center (A.R.C), Min istry of Agriculture, Giza, for support and helps to obtain spices and herbs which used in this investigation.

\section{REFERENCES}

[1] Field, R. A. (1988). Mechanically separated meat, poultry and fish. In A.M. Pearson, \& T. R. Dutson (Eds.), Edible meat by-products (pp. 83-128). London: Elsevier.

[2] Gray, J. L., Gomaa, E. A., \& Buckley, D. J. (1996). Oxidative quality and shelf life of meats. J. Meat Science, 43, S111-S123.

[3] Silva, F. A. M., Borges, M. F. M., \& Ferreira, M. A. (1999). Métodos para avaliação do grau de oxidação lipídica e da capacidade antioxidante. Quimica Nova, 22(1), 94-103.

[4] El-Alim, S. S. L. A., Lugasi, A., Hóvári, J., \& Dworchák, E. (1999). Culinary herbs inhibit lipid oxidation in raw and cooked minced meat patties during storage. J. Science of Food and Agriculture, 79(2), 277-285.

[5] Naveena, B. M., Sen, A. R., Vaithiy anathan, S., Babji, Y., \& Kondaiah, N. (2008). Comparative efficacy of pomegranate juice, pomegranate rind powder extract and BHT as antioxidants in cooked chicken patties. J. Meat Science, 80(4), 1304-1308.

[6] Rababah, T. M., Hettiarachchy, N. S., \& Horax, R. (2004). Total phenolics and antioxidant activities of fenugreek, green tea, black tea, grape seed, ginger, rosemary, gotu kola, and ginkgo extracts, vitamin $\mathrm{E}$, and terc-butylhydroquinone. J. Agricultural and Food Chemistry, 52(16), 5183-5186.

[7] Brannan, R. G., \& Mah, E. (2007). Grape seed extract inhibits lipid oxidation in muscle from different species during refrigerated and frozen storage and oxidation catalyzed by peroxinitrite and iron/ascorbate in a pyrogallol red model system. J. Meat Science, 77(4), 540-546.

[8] Dawidowicz, A. L., Wianowska, D., \& Baraniak, B. (2006). The antioxidant properties of alcoholic extracts from Sambucus nigra L. (antioxidant properties of extracts). J. Lebensmittel-Wissenschaft und Technologic, 39, 308-315.

[9] Lee, J.-Y., Hwang, W.-I., \& Lim, S.-T. (2004). Antioxidant and anticancer activities of organic extracts from Platycodon grandiflorum a. De Candolle roots. J. Ethnopharmacology, 93, 409-415.

[10] Mikkelson, V. L. (1993). Hamburger Patty Technology: A Literature Review. Technical Report, Meat Industry Research Institute of New Zealand (Inc.), MIRINZ 932 ISSN 0465-4390.

[11] A.O.A.C. (2000). Association of Official Analytical Chemists, 17th Ed. of A.O.A.C. International. Published by A.O.A.C. International. Maryland, U.S.A., 1250 pp.

[12] Lemon, D. W. (1975). An improved TBA test for rancidity. New series Circular No. 5., 145 pp.

[13] Abd-El-Qader, M. F. (2003). Quality Improvement of Chicken Frozen Burger Formulated with Some Spices or their Volatile Oils. M. Sc. Thesis, Food Science and Technology Dept., Faculty of Agric., Cairo Univ., Egypt.

[14] SPSS. (1998). SPSS for windows. Release, 9.0.0, Standard Version SPSS. Inc.

[15] Hegazy, N. E. (2004). Chemical, Micrbiological and Technological Studies on some Poultry Meat Products. M. Sci. Thesis, Food Industry Dept., Faculty of Agric., El-Mansoura Univ., Egypt.

[16] Ali, M. A. (2008). Effect of Processing and Cooking Method on Chemical, Biological and Microbiological Properties of Low- Fat Meat Products. Ph. D. Thesis, Food Science and Technology Dept., Faculty of Agric., Cairo, Univ., Egypt.

[17] Mohamed, H. A. (2005). Low Fat Products as Prepared from Ostrich and Other Produced Fat Beef. Ph. D. Thesis Nutrition and Food Science. Dept. Faculty of Home Economics. Minufiya University. Egypt.

[18] Bracco, U.; Loliger, J. and Viret, L. (1981). Production and use of natural antioxidants. J. AOCS 58: 686-690.

[19] Park, E. J.; Park, K. J. and Kim, Y. M. (1995). Quality changes of chicken meat during chilled and freeze storage. Korean J. Anim., Sci., 37 (3): 249-256.

[20] Abd-El-Kader, Z. M. (1996). Lipid oxidation in chicken as affected by cooking and frozen storage. Nahrung, 40 (1): 21-24.

[21] Abou Arab, A. A. and Abou Arab, E. A. (2004). Infulence of rosemary and sage extracts on deboned chicken meat quality. Minufiya J. Agric. Res. Vol. 1 No. 29: 169-180.

[22] Mohamed, H. M. and Mansour, H. A. (2008). Using natural herbal extracts for improving the lipid oxidation and sensory attributes of beef burger manufactured with mechanically deboned chicken meat. Vet. Med. J., Giza, 56 (4): 399-414.

[23] Dapkevicius, A.; Venskutonis, R.; Beek, T. A. and Linssen, J. P. H. (1997). Antioxidant activity of extracts obtained by different isolation procedures from some aromatic herbs grown in Lithuania. J. Sci., Food Agric., 77: 140-146. 
[24] Zheng, W. and Wang, S. Y. (2001). Antioxidant activity and phenolic Compounds in selected herbs. J. Food Chem., 49: $5165-5170$.

[25] E.O.S. (2005). The Egyptian Organization for Standerdization and Quality Control. Frozen beef burger. (1688).

[26] Liberman, S. G. and Petrovski, V. P. (1972). Reference Book on the Production of Food Animal Fats, Food Industry Pub., Moscow.

[27] Borowski, J. and Rotkiewicz, W. (1987). Effect of some heat treatment procedures on changes in turkey meat. III: Changes in protein and fat during frozen storage. Acta Academiae Agriculture-ac-Technica Olstenensis, Technologia Alimentorum (21): 35-41.

[28] Wally, F. A. (2002). Studies on Quality Attributes of Some Semifried Chicken Products During Freezing Storage. Ph. D. Thesis, Food Science and Technology Dept., Faculty of Agric., Cairo Univ., Egypt.

[29] Vaz, P. C.; Goncalves Rodrigues, A.; Pinto, E.; Costa-de-Oliveira, S.; Salgueiro, L.; Cavaleiro, C.; Goncalvas, M. J. and Martinez-de-Oliveira, J. (2004). Antifungal activity of thymus oils and their major compound. J. Eur Acad Dermatol Venereol, 18(1): 73-80.

[30] Lee, S. J.; Umano, K.; Shibamoto, T. and Lee K. G. (2005). Identification of volatile components in basil (Ocimum basilicum L.) and thyme leaves (Thymus vulgaris L.) and their antioxidant properties. Food Chem., 91 (1): 131-137.

[31] Botsoglou, N.; Taitzoglou, I.; Zervos, I.; Botsoglou, E.; Tsantarliotou, M. and Chatzopoulou, P. (2010). Potential of long-term dietary administration of rosemary in improving the antioxidant status of rat tissues following carbon tetrachloride intoxication. J. Food and Chemical Toxicology 48: 944-950.
[32] Usai, M.; Marchetti, M.; Foddai, M.; Caro, A.; Desogus,R.; Sanna, I. and Piga, A. (2011). Influence of different stabilizing operations and storage time on the composition of essential oil of thyme (Thymus officinalis L.) and rosemary (Rosmarinus officinalis L.). Food Sci. Tech., 44: 244-249.

[33] Amr, S. and Đorđević, S. (2000). The investigation of the quality of sage (Salvia Officinalis L.) originating from Jordan. J. Working and Living Environmental Protect., 1 (5): 103-108.

[34] Martos, V. M.; Ruiz-Navajas, Y.; Fernandez-Lopez, J. \& Angel Perez-Alvarez, J. (2008). Antibacterial activity of different essential oils obtained from spices widely used in mediterranean diet. Int. J. Food Sci. Tech., 43(3): 526- 531.

[35] Abdallah, M. A. (2000). Biochemical Studies on Some Medicinal Plants. Msc. Thesis (Agric. Biochemistry). Faculty of Agric., Cairo, Unvi.

[36] El-Ghorab, A. H.; Mansour, A. F. and El-Massary, K. F. (2004). Effect of extraction method on the chemical composition and antioxidant activity of Egyptian marjoram. Flavour Fragr. J., 19: 54-61.

[37] Karawya, M. S.; Hashim, F. M.; Abd El-Wahab, S. M.; El-Deeb, S. K.; Soliman, S. N. and Salam, I. A. (1994). Essential oil and lipids of Nigella sativa seeds and their biological activity. Zag. J. Pharm. Science, 3 (2) Augest.

[38] Abdullah, M. I. (1998). Changes Occurring in the Seeds of Some Spices in Response to the Treatment with Gamma Radiation. Ph. D. Thesis Botany Dept., Faculty of Sci., Al-Azhar Univ., Cairo, Egypt.

[39] Nagi, M. A. (2000). Protective effect of thymoquinone against doxorubicin induced cardiotoxicity in rats: A possible mechanism of protection. Pharmacological Res., 41: 283-289. 